\title{
Chalkbrood (Ascosphaera aggregata) resistance in the leafcutting bee (Megachile rotundata). I. Challenge of selected lines
}

\author{
WP Stephen *, BL Fichter \\ Oregon State University, Department of Entomology, Corvallis, OR 97331-2907, USA
}

(Received 20 April 1989; accepted 13 March 1990)

\begin{abstract}
Summary - Twenty-nine cell series of the leafcutting bee, Megachile rotundata (Fabr), each containing 5 or more healthy larvae, no chalkbrood (Ascosphaera aggregata Skou) and no pollen masses were isolated from a population with over $36 \%$ chalkbrood. This selected subpopulation was split and isolated for 4 and 6 generations before being challenged by forcing the females to nest in heavily contaminated media, or by weekly dustings with approximately $175 \times 10^{8} \mathrm{~A}$ aggregata spores. The incidence of chalkbrood in both challenged lines was markedly lower than that of the wildtype, and comparable to that of the selected lines, suggesting a genetic component for resistance in both lines. The very low incidence of pollen masses (dead eggs or early instar larvae) in the selected lines throughout the $4 \mathrm{yrs}$ of the study indicates that this trait may also be genetically mediated, either linked to, or independent of disease resistance.
\end{abstract}

chalkbrood / Ascosphaera / leafcutting bee / resistance / Megachlle

\section{INTRODUCTION}

Few studies have been conducted on resistance in endemic insects to naturally occurring pathogens. Most data deal with susceptibility differences among laboratory populations of insect pest species to viral (Martignoni and Schmid, 1961; Klein and Podoler, 1978) and bacterial pathogens (Harvey and Howell, 1965; Hoage and Rothenbuhler, 1966; Kinsinger and McGaughey, 1979; Georghiou et al, 1983). Among non-pest species, extensive studies have been conducted on resistance to viral pathogens among strains of Bombyx mori L (Watanabe, 1967; Briese, 1981), and 3 reports describe resistance to the "hairless-black syndrome" in honey bees (Bailey, 1965; Kulincevic and Rothenbuhler, 1975; Rinderer and Green, 1976). Resistance to chalkbrood, Ascosphaera apis, among colonies of honey bees was suggested by DeJong (1976), and large differences in susceptibility among silkworm populations to Beauveria bassiana (Aratake, 1961) and Aspergillus flavus (Kawakami, 1975) have been noted. The only direct selection for resistance to an entomogenous fungal pathogen cited in current literature is the study by Vansulin

\footnotetext{
* Correspondence and reprints
} 
(1974) in which the mortality in Culex pipiens molestus is halved after 8 generations of exposure to constant doses of $B$ bassiana.

Megachile rotundata ( $\mathrm{Fabr}$ ) is a gregarious Eurasian bee first recorded from the eastern United States in the mid 1930's (Mitchell, 1937). It spread rapidly across temperate North America reaching the western states by the late 1950's (Daly, 1952; Hurd, 1954). In 1959, when the bee was first recognized as a domesticable oligolege on alfalfa (Stephen, 1961; Stephen and Torchio, 1961), it was apparently ubiquitous throughout the Pacific Northwest with its numbers limited by the availability of suitable nesting sites. Populations increased rapidly through trap nesting and, by 1962 , large commercial operations in bee sales were established.

The leafcutting bee propagation industry has been centered in western Canada for more than a decade with annual commercial sales of 200 to 300 million cells, principally to alfalfa seed producers in the western United States. We suggest that these importations, extensive local and regional commerce, as well as the tendency of the species to disperse widely have prevented the development of locally adapted populations of the bee. The result is a near continuous array of highly adaptable, poorly adapted local populations throughout western America. The rate at which chalkbrood has spread tends to support this idea.

Chalkbrood is a fungal disease of leafcutting bee larvae (Megachile rotundata (Fabr) caused by Ascosphaera aggregata Skou, and was first identified from Nevada populations in 1973 (Thomas and Poinar, 1973). It spread rapidly throughout all areas of the western United States in which the bee was propagated and is now cosmopolitan (Stephen et al, 1981). This disease is the principal limiting factor to bee production, accounting for losses up to $75 \%$ in some areas of the Pacific Northwest (Stephen et al, 1981). Chalkbrood is spread by spores in contaminated nesting media and by spores carried on the body surface of adult bees (Vandenberg et al, 1980). Spores deposited in cell provisions are ingested by a developing larva and germinate in the gut. The mycelia penetrate the gut wall and rapidly fill the hemocoel (Vandenberg and Stephen, 1982; McManus and Youssef, 1984). At present, there is no effective control for the disease other then prophylactic measures directed at reduction of inoculum (Stephen and Undurraga, 1978; Kish et al, 1981).

Although various materials are used as nesting media for the bee, paper soda straws are the medium of choice for population monitoring. Selected soda straws can be removed from a box without disruption of the cell series and their contents can be evaluated through $\mathrm{X}$-ray analysis (Stephen and Undurraga, 1976). The cells in a nesting tunnel (from 1-12) are usually those of a single female. We examined thousands of straws while monitoring bee populations in the western United States for chalkbrood. In heavily diseased populations, cadavers occur in a near-random distribution within and among straws, but occasionally an entire series of from 5-10 cells in a single straw will be found to be disease-free. As only 500 to 1000 spores constitute an LD $_{50}$ (Fichter and Stephen, unpublished), and nearly $10^{8}$ spores are carried by a single female (Vandenberg et al, 1980), it is highly improbable that an entire nesting tunnel in a heavily diseased population could escape inoculation.

Thus, the premise of these studies was that, if all the progeny of a single female were chalkbrood-free in a population with more than $35 \%$ diseased larvae, genetically-mediated factors for disease resistance may be present in the population. Our ob- 
jectives were to demonstrate that intrapopulation differences in pathogen susceptibility exist and that through selection and challenge, disease resistance lines may be established.

\section{MATERIALS}

\section{Oregon stock}

A population of leafcutting bees near Adrian, Oregon with $36.1 \%$ chalkbrood was chosen as the wild type (WT) from which selections were made. Approximately 10000 straws were $X$ rayed at the end of the 1977 season. Only straws containing 5 or more healthy larvae and no chalkbrood or pollen masses were selected: a total of 29 straws with from 5-9 live cells each formed the base population from which expansion was made.

\section{Study sites}

The straws were incubated and placed out for increase in 1978 at 2 sites near Los Molinos, CA. The sites were approximately $7 \mathrm{~km}$ apart with walnut and almond orchards intervening. Both sites were carefully surveyed and trapnested in 1977 and no $M$ rotundata were found. Approximately half of the selected material was placed at each site with new, brown paper soda straws provided for renesting. Cells from the 2 sites were designated Lines A and B. Los Molinos was selected as the principal experimental area because of its long, dry summer season during which at least 3 generations of the leafcutting bee could be reared and because of the relatively low endemic bee populations. All but 2 (original) replication sites had to be abandoned during the 4-year study period because our selected lines were swamped by in-flight from endemic bee populations. Thus, replications were confined to data gathered from individual cartons placed at different locations at the same site. Outbuildings at each site were sprayed with Dibrom in late May and/or early June of each year to eliminate any residual population of bees. A 2nd location near Nyssa, OR was utilized to test the protocol for the chalkbrood challenge studies.

\section{Expansion and selection}

All bees were reared in $9 \mathrm{~cm}$ long $\times 5.5 \mathrm{~mm}$ diameter brown, paper soda straws packed tightly in cartons with approximately 250 straws each. Tight packing permitted the removal of capped straws and replacement with new without altering the position of other straws. Each spring, bees were incubated at $30^{\circ} \mathrm{C}$ until emergence of the first males after which they were placed into the field. Every $10 \mathrm{~d}$ after field placement, capped straws were color-coded and left in situ for an additional $20 \mathrm{~d}$ to mature. They were then removed from the carton and returned to the laboratory for X-ray analysis. Live larvae, chalkbrood, dead larvae, pollen masses (= provisioned cells with no eggs or with dead eggs or early instar larvae), and parasitism were recorded. Any straw containing a chalkbrood cadaver was removed and destroyed during the expansion phase. No spore challenges were made during the 1st 4 generations of expansion. Cells parasitized by Tetrastichus spp were removed from each straw to avert a build-up of parasites during the season. The remaining straws were returned to their original sites for emergence and renesting of the subsequent generation.

\section{METHODS}

\section{Experiment I}

To ascertain whether the selected lines were resistant to chalkbrood, the 4th expansion generation was forced to nest in soda straws heavily contaminated with chalkbrood. Six straw cartons, used for propagation of the Adrian wild type (=WT) population in 1977 and 1978 and heavily contaminated with chalkbrood, were selected for this test. Each carton contained approximately 220 straws, all of which were capped indicating that each had been occupied (and presumably provisioned) at some time during the $2 \mathrm{yr}$ period. Two cartons were destruc- 
tively sampled for 150 straws each and 30 capped straws were selected haphazardly from each of the remaining 4 cartons. All straws were $X$-rayed to determine live larvae, chalkbrood and pollen masses. Two of the latter cartons were laboratory incubated in March 1979 to remove all live bee larvae and parasitoids; and the remaining 2 were kept as Adrian 1979 WT Controls.

Incubation of the 2 WT cartons (above) resulted in emergence from fewer than $30 \%$ of the straws, ie the caps were not disrupted on the remaining straws suggesting that they contained only chalkbrood cadavers, pollen masses, and dead larvae. As nesting females will only accept tunnels which are uncapped or those in which the cap has been disrupted, and, as our objective was to expose the renesting selected population to a maximum amount of inoculum, the caps of all straws were pierced with a $3 \mathrm{~mm} x$ $10 \mathrm{~cm}$ reamer and the contents of the straw carefully disrupted along its entire length. Care was taken to minimize the loss of inoculum during the reaming process. Thirty-three and 34 straws containing 220 and 221 live larvae of the 4th expansion generation (Select Line B) were introduced into these 2 WT cartons and placed in a field south of Gerber, CA. Emergents were thus forced to accept contaminated nesting media.

Caps of all straws in the 21979 WT Control cartons were pierced and disrupted to a depth of approximately $1.25 \mathrm{~cm}$ so as to provide the emerging population with access to an adequate supply of tunnels. Such disruption was shallow enough to avoid damage to most if not all cells in each straw, yet deep enough to provide searching females with ready access to the tunnel. To maintain isolation it was necessary to locate the WT Controls in a field $24 \mathrm{~km}$ west of Los Molinos. Controls for Select B 5th expansion generation were re-established at the Los Molinos site.

Emergence began on July 23 and nesting was allowed to continue until August 31 (table I). Capped straws in each of the 6 cartons were painted on August 11 and August 31, permitted to develop for 2 weeks under field conditions, and then removed for $\mathrm{X}$-ray analysis. Cells of all capped straws of each population were evaluated for live larvae, chalkbrood and pollen masses. The pollen mass category was included because it was suspected (and later confirmed
[Fichter and Stephen, unpublished]) that early instar larvae could be killed after ingesting large amounts of $A$ aggregata inoculum. Second (and often early third) instar larvae killed by the fungus are difficult and often impossible to identify on the X-ray plate. Thus, any abrupt decrease in the incidence of 5 th instar chalkbrood cadavers which may be accompanied by a comparable increase in pollen masses could reflect a difference in the stage at which mortality occurred rather than a real diminution of the disease.

\section{Experiment II}

An evaluation of the efficacy of the chalkbrood challenging procedure under field conditions was undertaken in 1980 on 2 populations of leafcutting bees located north of Nyssa, Oregon.

The Nyssa site was selected because local Californian populations of the size necessary for these tests did not exist, and because we wished to avoid any introductions which would jeopardize the isolation of our selected lines. One population was derived from a 1979 chalkbrood-free Canadian source; the 2nd from regionally trapped bees with a low incidence of chalkbrood $(7.2 \%$ at the end of 1979). Each population was housed in different domiciles and was propagated in drilled wooden boards from which cells could be removed.

\section{Inoculum preparation}

Inoculum was prepared using 1977 Adrian wild type (WT) paper soda straw nesting medium. $X$ ray analyses indicated that each carton contained approximately 700 chalkbrood cadavers (table I). All straws were removed from 1 carton and macerated in a blender. The residual paper was then removed, the contents passed through a 10-mesh screen to remove pieces of leaf matter and matted pollen, and the screenings thoroughly pulverized in a mortar. One quarter of the pulverized contents of each WT carton was dusted into each straw carton prior to field placement, and at weekly intervals thereafter. A hand-operated piston-type duster was used for spore inoculation. It is estimated that each cadaver produces from $10^{8}-10^{9}$ spores (Stephen, 
Table I. Selected line B of $M$ rotundata challenged with contaminated nesting medium (Los Molinos, CA 1979).

* Total is less than $100 \%$ as cells parasitized and/or with dead larvae are not included.

\begin{tabular}{cccccc}
\hline Material & $\begin{array}{c}\text { Sample } \\
\text { date }\end{array}$ & $\begin{array}{c}\text { \% Live } \\
\text { larvae }\end{array}$ & $\begin{array}{c}\% \text { Chalk } \\
\text { brood }\end{array}$ & $\begin{array}{c}\text { Pollen } \\
\text { mass \% }\end{array}$ & $\begin{array}{c}\text { Total } \\
\text { cells }\end{array}$ \\
\hline $\begin{array}{c}\text { Select line B 1979 } \\
\text { 4th expansion gen }\end{array}$ & $6 / 02-21$ & 92.3 & 2.3 & $3.6^{*}$ & 478 \\
$\begin{array}{c}\text { Adrian Wild Type (WT) } \\
\text { Contaminated Stock }\end{array}$ & $1977-78$ & 14.6 & 55.1 & 30.3 & 2320 \\
$\begin{array}{c}\text { Select B - renest } \\
\text { in 1978 WT straws }\end{array}$ & $7 / 23-8 / 31$ & 77.7 & 12.1 & 2.9 & 1268 \\
$\begin{array}{c}\text { Select B Control } \\
\text { 5th expansion gen }\end{array}$ & $7 / 23-8 / 31$ & 91.6 & 3.4 & 3.1 & 1537 \\
$\begin{array}{c}\text { Adrian WT control } \\
\text { renest in WT 1979 }\end{array}$ & $7 / 23-8 / 31$ & 33.1 & 33.4 & 26.0 & 329 \\
\hline
\end{tabular}

unpublished) and each carton received approximately $175 \times 10^{8}$ spores weekly.

The experiments were initiated on July 18 1980 , approximately 2 wks after each population had emerged and when the bees were actively nesting. One board from each of 4 field domiciles containing active nesting populations of either Canadian (2 domiciles) or Nyssa (2 domiciles) females was removed on the morning of July 18 and was replaced with 2 new straw cartons inoculated with 1977 Adrian WT inoculum prepared as described above. Two boards were removed from the far side ( $3-5 \mathrm{~m}$ distant) of each of the same domiciles and replaced with 4 straw cartons to serve as controls. Females from the displaced boards began provisioning the inoculated straws by late morning. Straws were dusted with Adrian WT inoculum at approximately weekly intervals (4 applications) until August 10 , when flight had ceased. Test straws were removed from the field on August 20 . Four cartons located approximately $3 \mathrm{~m}$ from the test cartons in each field domicile were removed on September 3 and served as controls for each population. Forty capped straws were removed from each of the Nyssa challenged cartons, 50 from each of the Canadian challenged cartons, and 50 from each carton serving as controls to the 2 populations to determine the effect of the challenging method on the incidence of chalkbrood, live larvae and pollen masses. Selection of capped straws was not random for the number of capped straws ranged from 42-177 per carton among the 24 cartons used in this test.

\section{Experiment III}

Chalkbrood resistance in the 6th expansion generation of selected line $A$ was field evaluated by challenging with inoculum.

In June 1980, 136 straws containing 791 live larvae of the 6th expansion generation were divided with equal numbers placed in each of 4 cartons of new straws prior to emergence. Because of limited isolation sites, each carton was located on different out-buildings of adjacent farmyards, separated by distances of 150-750 $\mathrm{m}$. Inoculum to challenge the selected line was prepared as described above. One-fourth of the pulverized contents of each 1977 Adrian WT 
carton was dusted into each of the 4 cartons containing selected bees prior to their emergence. This procedure was repeated weekly for 8 wks with each application of inoculum made in the morning before females began foraging. Dusting was terminated on August 8 and cartons removed for analysis on August 19. An isolated population of the selected line served as a Select Line A 1980 control (7th expansion gen). Four cartons of straws were each supplied with 200 cells from the same susceptible Canadian bee population used in Exp II. In this experiment 2 cartons served as "challenge" controls (Canada, 1980) and were inoculated as described above. Two cartons were isolated in a field 11 km south of Corning as controls. Cartons were removed from the field between August 19 and 21. All capped straws from each treatment were $X$-ray analysed for live larvae, chalkbrood and pollen masses.

\section{RESULTS}

The progeny of selected line B females forced to nest in heavily contaminated straws (Exp I) showed an increase in chalkbrood from 2.3 to $12.1 \%$, a decrease in live larvae from 92.3 to $77.7 \%$ and no change in the proportion of pollen masses. Chalkbrood increased $10 \%$ in the Select B line as a result of the challenge, but this was more than $21 \%$ less than the disease incidence in the unselected population. The controls for the selected line (Select B 5th expansion gen) were almost identical to the 1978 populations from which it was taken (Select B 4th expansion gen) (table I). Analysis of the Adrian WT contaminated straws 1978 was made prior to the laboratory emergence of bees and represents the status of the material used both as the source for inoculum and as the Adrian WT 1979 control for this experiment (table I). Analysis of the Adrian controls was confined to those straws in which females had nested during the 1979 season, as the inclusion of all previous cadavers and pollen masses in the calculations would have highly biased the data. This accounts for the apparent doubling of live larvae and sharp reduction in chalkbrood incidence in the Adrian WT 1979 control compared to those categories in the Adrian WT 1978 Stock. The latter data include all cells constructed during both the 1977 and 1978 seasons (table I).

Data in table II indicate that the method of field inoculation for chalkbrood was effective. Chalkbrood in the unchallenged endemic population increased from 7.6 to $15.7 \%$ during 1980 , while that of the challenged rose to $27.1 \%$. The incidence of disease in the challenged Canadian material was $26.4 \%$ whereas that of the unchallenged was $3.8 \%$. Both challenged populations had fewer live larvae and fewer pollen masses than the controls (table II).

There was little difference between challenged and control populations on selected Line $A$ in chalkbrood $(5.0$ vs $2.8 \%$ ) or pollen masses (3.2 vs 2.8\%) (table III). The proportion of live larvae remained high in both populations (90 and $93 \%$ ) both higher than that of the populations from which they were derived. The spore challenges, however, resulted in $27.8 \%$ chalkbrood in the chalkbrood-free Canadian material used as the challenge control (table III). Chalkbrood incidence in subsamples of the Canadian population challenged in Oregon (Exp II) and in California (Exp III) was nearly identical (26.4 vs $27.8 \%$ ) even though the latter was given 2 more treatments of inoculum (the population had died off by the 1st wk in August). The Canada (80) challenged population suffered bird damage during the 1st 2 wks of flight and thus reproduction was lower than expected. The Canadian 1980 controls were swamped by inflight of endemic $M$ rotundata beginning during the 2 nd wk (table III). 
Table II. Unselected lines of $M$ rotundata challenged with chalkbrood inoculum weekly for 5 wks. (Nyssa, OR 1980).

* Total is less than $100 \%$ as cells parasitized and/or with dead larvae are not included. ** Overwintering population from which samples were drawn for 1980 tests.

\begin{tabular}{|c|c|c|c|c|c|}
\hline Material & $\begin{array}{c}\text { Sample } \\
\text { date }\end{array}$ & $\begin{array}{l}\text { \% Live } \\
\text { larvae }\end{array}$ & $\begin{array}{c}\% \text { Chalk } \\
\text { brood }\end{array}$ & $\begin{array}{l}\text { Pollen } \\
\text { mass }\end{array}$ & $\begin{array}{l}\text { Total } \\
\% \text { cells }\end{array}$ \\
\hline Nyssa ('79) Wild type ${ }^{* *}$ & 1979 & 60.8 & 7.6 & $20.6^{\star}$ & 992 \\
\hline Nyssa ('80) Challenge & 18 July-20 Aug & 50.0 & 27.1 & 17.6 & 642 \\
\hline Nyssa ('80) Control & 18 July-03 Sept & 57.6 & 15.7 & 21.2 & 827 \\
\hline Canada (79) Wild type** & 1979 & 89.3 & 0 & 6.7 & 1234 \\
\hline Canada (80) Challenge & 18 July-20 Aug & 54.0 & 26.4 & 16.2 & 893 \\
\hline Canada (80) Control & 02 July-03 Sept & 62.4 & 3.8 & 21.2 & 911 \\
\hline
\end{tabular}

Table III. Selected line A of $M$ rotundata challenged with chalkbrood inoculum weekly for 8 wks. (Los Molinos, CA 1980).

* Total is less than $100 \%$ as cells parasitized and/or with dead larvae are not included.

\begin{tabular}{|c|c|c|c|c|c|}
\hline Material & $\begin{array}{l}\text { Sample } \\
\text { date }\end{array}$ & $\begin{array}{l}\text { \% Live } \\
\text { larvae }\end{array}$ & $\begin{array}{c}\% \text { Chalk } \\
\text { brood }\end{array}$ & $\begin{array}{l}\text { Pollen } \\
\text { mass }\end{array}$ & $\begin{array}{l}\text { Total } \\
\% \text { cells }\end{array}$ \\
\hline $\begin{array}{l}\text { Select line A } 1979 \\
\text { 6th expansion gen }\end{array}$ & 1979 & 86.2 & 4.9 & $3.8^{*}$ & 917 \\
\hline $\begin{array}{l}\text { Select line A } 1980 \\
\text { challenged }\end{array}$ & 19 Aug 1980 & 90.3 & 5.0 & 3.2 & 3448 \\
\hline $\begin{array}{l}\text { Select A control } \\
7 \text { th expansion gen }\end{array}$ & 19 Aug 1980 & 93.1 & 2.8 & 2.8 & 1175 \\
\hline Canada Wild type & 1979 & 89.3 & -0 & 6.7 & 1234 \\
\hline $\begin{array}{c}\text { Canada } 1980 \\
\text { challenged }\end{array}$ & 19 Aug 1980 & 64.8 & 27.8 & 5.5 & 907 \\
\hline $\begin{array}{l}\text { Canada } 1980 \\
\text { control }\end{array}$ & \multicolumn{5}{|c|}{ (population swamped by inflight) } \\
\hline
\end{tabular}




\section{DISCUSSION}

The method used to challenge nesting female bees with inoculum appears to the effective; the incidence of chalkbrood in both the Nyssa and Canadian lines, treated identically over 4 wks, increased from 7.6 to $27.1 \%$ and 0 to $26.4 \%$ respectively (table II). The chalkbrood increase from 7.6 to $15.7 \%$ in the endemic line is consistent with the expected rate of disease increase in an isolated population (Stephen unpublished), but the $3.8 \%$ chalkbrood in the unchallenged Canadian population after $1 \mathrm{yr}$ of expansion is considerably less than expected. We assume that inflight of contaminated endemic adults to this site was minimal. The efficacy of the method is further supported by the increase in chalkbrook from 0 to $27.8 \%$ as a result of challenging a subsample of the same chalkbrood-free Canadian population (above) in California (table III).

Progeny of Line A females which were dusted with spores from the equivalent of 179 cadavers each wk for 8 wks, did not differ appreciably in chalkbrood, live larvae or pollen masses from those of the control or the 1979 stock from which they were derived (table III). This strongly suggests that a genetic component for disease resistance is present.

Chalkbrood was much higher in the progeny of females renesting in heavily contaminated soda straws (Exp I) than in those of females challenged with chalkbrood spores by dusting (Exp III) (12.1 vs $5.0 \%$ ). This may suggest that : Line $A$ was more resistant to the disease than Line B as Line $A$ was in its 6 th expansion generation and Line $B$ in its 4 th when challenged; or, the 2 methods of challenging differ in their efficacy - spores were applied at weekly intervals in the latter and were present continuously from the onset of nesting in the former (Line B). Although both lines $A$ and $B$ were derived from the same population, each was expanded from a limited gene pool, the progeny of 14 and 15 females respectively. It is improbable that factors conferring disease resistance exhibit any form of dominance, for there is no evidence of the rapid spread of the trait during the 10 years chalkbrood has been a problem. If we assume that resistance in these two lines is recessive and polygenic, it is probable that allelic components for resistance in the 2 lines differed at the time of testing.

Chalkbrood in the challenged chalkbrood-free Canadian population was comparable $(26.4 \%)$ to that of the challenged endemic bees $(27.1 \%$ ) (table II). There is a widely held belief among leafcutting bee consumers in the USA that Canadian bees are far more susceptible to chalkbrood than endemic US populations. While Exp II was not directed towards answering that question, the data suggest that if differences in susceptibility exist, they are minor, at least in the Canadian population used in this study.

An interesting observation in these experiments relates to pollen masses. As indicated above, pollen masses result from the absence or death of an egg or early instar larva, leaving the unconsumed provision in the cell. In most areas of the Pacific Northwest, pollen masses rank second only to chalkbrood as identifiable mortality in leafcutting bee populations, commonly 15 to $35 \%$ (see tables I and II). Nest exposure to direct sunlight is known to cause early instar mortality (Undurraga, 1975) and various other factors such as pesticides and nectar dearth have been suggested as causes. In the original selections from the Adrian WT population, we chose only straws containing $\mathbf{5}$ or more live larvae, and concomitantly, no cells with pollen masses. During the entire period of selection and expansion, the incidence of 
pollen masses never exceeded $4.4 \%$. The pollen mass trait may also be genetically mediated, either linked to, or independent of, disease resistance.

\section{ACKNOWLEDGMENTS}

Technical Paper No. 9065 Oregon Agricultural Experiment Station. Supported in part by USDA ARS Cooperative Agreement No 58-9AHZ-3730.

Résumé - Résistance au couvain plâtré (Ascosphaera aggregata) chez la mégachile (Megachile rotundata). I. Test de lignées sélectionnées. Vingt neuf séries de cellules de l'abeille Megachile rotundata (Fabr) ont été sélectionnées à partir d'une population présentant un taux de couvain plâtré, ou ascosphériose (Ascosphaera aggregata Skou), de $36,1 \%$. Seules les séries comprenant 5 larves saines ou plus, pas de couvain plâtré ni de masses polliniques ont été retenues (la présence de masses polliniques indique que l'œuf, ou la jeune larve, est mort). La moitié de la population s'est reproduite pendant 4 générations puis nous avons testé sa résistance en forçant les femelles à nidifier dans des matériaux fortement contaminés. Le taux de couvain plâtré parmi la descendance est passé de 2,3 à $12,1 \%$ (tableau I) mais cela représente une baisse de $60 \%$ par rapport à la population sauvage d'origine. Lors d'une série de tests menés pour déterminer l'efficacité de l'induction du couvain plâtré parmi des lignées de mégachiles non sélectionnées, nous avons fait macérer des pailles à boire fortement contaminées. Le produit obtenu a été tamisé, pulvérisé et saupoudré dans les matériaux de nidification à intervalles d'une semaine. Cette méthode s'est montrée efficace : l'incidence du couvain plâtré est passée de 7 à $27 \%$ dans les populations testées (tableau II).
La seconde moitié des séries sélectionnées s'est multipliée durant 6 générations puis a été testée avec environ $175 \times 10^{8}$ spores chaque semaine pendant 8 semaines. La différence a été faible entre les populations testées et les témoins $(5,0$ contre 2,8\%) (tableau III). Les données suggèrent qu'une composante génétique de résistance au couvain plâtré était présente dans les 2 lignées d'abeilles. La très faible fréquence des masses polliniques dans les 2 lignées tout au long des 4 années d'étude $(2,8$ et $3,8 \%)$ contraste fortement avec celui présent chez le type sauvage $(20 \%)$, suggérant que cette caractéristique peut être également déterminée génétiquement, soit en liaison avec, soit indépendamment de la résistance à la maladie.

Megachile rotundata / Ascosphaera / couvain plâtré / résistance

Zusammenfassung - Kalkbrut- (Ascosphaera aggregata) Resistenz bei der Blattschneidebiene (Megachile rotundata). I. Prüfung selektierter Linien unter harten Bedingungen. Aus einer Population der Blattschneidebiene (Megachile rotundata Fabr) mit einem Befall von 36,1\% Kalkbrut (Ascosphaera aggregata Skou) wurden 29 Zellserien ausgewählt. Es wurden nur Serien ausgesucht, die fünf oder mehr gesunde Larven und keine Kalkbrut oder Pollenmassen enthielten (Pollenmassen sind Anzeichen dafür, daB das Ei oder die junge Larve abgestorben ist). Die Hälfte der Population wurde vier Generationen hindurch vermehrt und dann auf ihre Resistenz streng geprüft, indem man die Weibchen zwang, in schwer verseuchtem Material zu nisten.

Die Kalkbrut stieg in diesem Test bei der Nachkommenschaft von 2,3 auf $12,1 \%$ an, aber das war um $60 \%$ weniger als bei 
der Wildpopulation, von der sie herstammte. In einer Versuchsserie, in der die Wirksamkeit der künstlichen Kalkbrutauslösung bei nicht selektierten Linien geprüft werden sollte, wurden schwer kontaminierte Getränke-Halme mazeriert, dann gesiebt und pulverisiert; schließlich wurde das Nestmaterial mit den Sporen in Intervallen von je einer Woche bestäubt. Diese Methode enwies sich als wirksam, da sie den Kalkbrut-Befall in den Testpopulationen von 7 auf $27 \%$ erhöhte. Die zweite Hälfte der Population wurde 6 Generationen hindurch vermehrt und anschließend durch Bestäuben mit etwa $175 \times 10^{8}$ Sporen wöchentlich für 8 Wochen geprütt. Es bestand ein nur geringer Unterschied zwischen den geprüften Zuchten und den selektierten Kontrollen (5,0 gegen 2,8\%). Diese Daten lassen vermuten, daß in beiden Linien eine genetische Komponente für Krankheitsresistenz bestand. Das auffallend niedrige Vorkommen von Pollenmassen in beiden Linien während der vier Jahre der Untersuchung $(2,8$ bis $3,8 \%$ ) stand in starkem Gegensatz zu der Häufigkeit von Pollenmassen in der Wildpopulation (über $20 \%$ ). Dies legt die Vermutung nahe, daß auch dieses Merkmal genetisch übertragen wird, entweder gekoppelt oder unabhängig von der Kalkbrutresistenz.

\section{Megachile rotundata / Ascosphaera / Kalkbrut / Resistenz}

\section{REFERENCES}

Aratake $Y$ (1961) Genetic analyses of the infection with muscardines of Bombyx mori L. I. Infection with the white muscardine. Bull Seric Exp Stn (Tokyo) 17, 136-165

Bailey L (1965) Paralysis of the honey bee, Apis mellifera Linnaeus. J Invertebr Pathol 7, 132140

Briese DT (1981) Resistance of insect species to microbial pathogens. In : Pathogenesis of
Invertebrate Microbial Diseases (Davidson EW, ed), 511-545

Daly HJ (1952) Records of Palearctic Megachile rotundata in the United States. Entomol News 63, 210-211

DeJong D (1976) Experimental enhancement of chalkbrood infections. Bee World 57, 114115

Georghiou GP, Baker J, Al-Khatib Z, Mellon R, Murray $\mathrm{C}$, Tran $\mathrm{H}$, Vasquez $\mathrm{M}$, Pelsue $\mathrm{F}, \mathrm{Ha}$ zelrigg $J(1983)$ Insecticide resistance in mosquitoes : Research on new chemicals and techniques for management. Mosquito Control Research, Annual Report University California

Harvey TL, Howell DE (1965) Resistance of the housefly to Bacillus thuringiensis. J Invertebr Pathol 7, 92-100

Hoage TR, Rothenbuhler WC (1966) Larval honeybee response to various doses of Bacillus larvae spores. J Econ Entomol 59, 42-45

Hurd PD Jr (1954) Distributional notes of Eutricharea, a Palearctic subgenus of Megachile, which has become established in the United States. Entomol News 65, 93-95

Kawakami K (1975) Susceptibility of several varieties of the silkworm, Bombyx mori L to Aspergillus disease and germination of fungus spores in larval hemolymph. $J$ Seric Sci (Jpn) 44, 39-44

Kinsinger RA, McGaughey WH (1979) Susceptibility of populations of Indian meal moth and Almond moth to Bacillus thuringiensis. $J$ Econ Entomol 72, 346-349

Kish LP, Waters ND, Homan HW (1981) Chalkbrood. University of Idaho. Agric Exp Stn Current Info Series No 477

Klein M, Podoler H (1978) Studies on the application of a nuclear polyhedrosis virus to control populations of the Egyptian cotton worm, Spodoptera littoralis. J Invertebr Pathol 32, 244-248

Kulincevic JM, Rothenbuhler WC (1975) Selection for resistance and susceptibility to hairless-black syndrome in the honeybee. $J$ lnvertebr Pathol 25 (3), 289-295

Martignoni M, Schmid P (1961) Studies on the resistance to virus infection in natural populations of Lepidoptera. J Insect Patho/ 3, 62-74

McManus WR, Youssef NN (1984) Life cycle of the chalkbrood fungus, Ascosphaera aggreg- 
ata, in the alfalfa leafcutting bee, Megachile rotundata, and its associated symptomatology. Mycologia 76, 830-842

Mitchell TB (1937) A revision of the genus Megachile in the Nearctic region. Pt. VIII: Taxonomy of the subgenus Chelostomoides, addenda and index. Trans Am Entomol Soc 63, $381-426$

Rinderer TE, Green TJ (1976) Serological relationship between chronic bee paralysis virus and the virus causing hairless-black syndrome in the honeybee. J Invertebr Pathol 27, 403-405

Stephen WP (1961) Artificial nesting sites for the propagation of the leafcutter bee, Megachile (Eutricharea) rotundata (Fabr) for alfalfa pollination. J Econ Entomol 54, 989-993

Stephen WP, Torchio PF (1961) Biological notes on the leaf-cutter bee, Megachile rotundata (Fabr). Pan-Pac Entomol 37, 85-93

Stephen WP, Undurraga JM (1976) Xradiography, an analytical tool in population studes of the leafcutter bee, Megachile pacifica. J Apic Res 15, 81-87

Stephen WP, Undurraga JM (1978) Chalkbrood disease in the leafcutting bee. Oregon State Univ Agric Exp Stn Bull 630
Stephen WP, Vandenberg JD, Fichter BL (1981) Etiology and epizootiology of chalkbrood in the leafcutting bee, Megachile rotundata, with notes on other Ascosphaera species. Oregon State Univ Agric Exp Stn Bull 653

Thomas GM, Poinar GE Jr (1973) Report of diagnoses of diseased insects, 1962-1972. Hilgardia 42, 261-359

Undurraga JM (1975) Factors affecting the increase of the alfalfa leafcutter bee. Proc VI Ann Alfalfa Seed Growers Short Course. Oregon State Univ Corvallis, OR, 14-25

Vandenberg JD, Stephen WP (1982) Etiology and symptomatology of chalkbrood in the alfalfa leafcutting bee, Megachile rotundata. $J$ Invertebr Pathol 39, 133-137

Vandenberg JD, Fichter BL, Stephen WP (1980) Spore load of Ascosphaera species on emerging adults of the leafcutting bee, Megachile rotundata. Appl Environ Microbiol 39, 650-655

Vansulin SA (1974) On the resistance of Culex pipiens molestus Forsk. to Boverin. Parazitologiya (Leningr) 8, 274-275

Watanabe $H$ (1967) Development of resistance in the silkworm, Bombyx mori, to peroral infection of a cytoplasmic-polyhedrosis virus. $J$ Invertebr Pathol 9, 474-479 